\title{
Is vital pulp therapy fiction or a real treatment option?
}

\section{Rebeca Weisleder*}

Department of Endodontics, University of Missouri Kansas City, Kansas City, USA

Managing immature teeth with pulp exposures due to traumatic injuries or gross caries has become more common, particularly with the introduction of new restorative materials containing calcium silicate cements. These new materials have demonstrated the capacity to maintain tissue viability for the duration of dental organ development and closure of the apical root. Historically, calcium hydroxide has been the medicament of choice for traumatic injuries, according to several publications, as it provided the adequate environment for the formation of mineralized tissue due to its high $\mathrm{pH}$ and disinfecting properties [1]. Currently, with the development of MTA and other bioceramic materials, techniques have evolved and new opportunities exist for treatment instead of extraction. MTA is composed of tricalcium silicate, bismuth oxide, dicalcium silicate, tricalcium aluminate, and calcium sulfate dihydrate. This material has demonstrated its ability to induce hard tissue formation and to have a success rate of 93 to $100 \%$ when used in pulpotomies with caries pulp exposure in young permanent teeth [2].

Choosing the right material for the task has also been documented in the literature. These materials should be bacteriocidal, have the ability to induce hard tissue formation, and be able to create a tight seal that will prevent micro-leakage, thus preventing reinfection [2].

Case selection is also key for the success of this treatment modality. Previous pain, current signs and symptoms, sensibility testing, and radiographic images, are among the variables that need to be taken into consideration. Spontaneous pain, percussion or palpation sensitivity, as well as periapical radiolucencies, are predictors for failure. Other factors have an impact on vital pulp therapy [3,4]. The operator's experience, the capability to acquire the necessary materials, and the access to the right facilities play an important role, as well as, the economic aspect, which determines the patient's decision to continue with treatment or extract the tooth. Some research suggests that an interim treatment option for teeth with irreversible pulpitis is a eugenol pulpotomy using IRM or glass ionomer as temporary restoration. This would allow the patient to have some time to gather the necessary means for root canal treatment being pain free for six months [5].

So what is all the buzz about vital pulp therapy? Should we pay attention? The answer is yes. The reality is that although implants have a good success rate and are a treatment modality for the loss of a tooth, young patients have to wait until they finish their growth spurt to become a candidate to receive it. There are many other factors involved which have a great impact on making the decision or even being a right aspirant for implant therapy. These involve patient's systemic and oral health, patients' habits, quality and quantity of bone present, periodontal factors, as well as potential for procedural complications [6].

Preserving teeth in young patients could turn to be a pivotal factor in maintaining bone structure for implant placement in a later stage of life. It has been shown that teeth are very important for the correct growth of the maxilla and it is of utmost importance to make any effort to avoid extraction [7]. Vital pulp therapy plays an important role in providing individuals with other opportunities to save teeth and keep their options open for further treatments when needed.

Vital pulp therapy includes direct pulp capping, partial pulpotomies, and complete pulpotomies. Each modality encompasses a different procedure. Direct pulp capping is defined as the use of dental material as a dressing to maintain pulpal vitality and health after a pulp exposure due to caries or trauma [8]. Partial pulpotomy was defined by Cvek as the partial removal of the coronal pulp adjacent to the exposure [9] and complete pulpotomy is the eradication of coronal pulp tissue and placement of a dressing on the canal orifice [4]. Each one has a different success rate depending on the study; some studies report that direct pulp capping has a $96.97 \%$ success rate [3], partial pulpotomy oscillates between 87 and $100 \%$ success [4], and complete pulpotomy variates between the 70 and $90 \%$ [10]. The materials used may influence the outcomes.

The permanent restoration used also plays a crucial role. Kakehashi, Stanley and Fitzgerald showed in their research that bacterial presence is critical in healing exposed pulps [11], therefore, picking the right material is a critical factor,

In summary, vital pulp therapy provides an additional viable option for the treatment of immature permanent teeth with vital pulps allowing the preservation of tissue necessary for the maturation and apexogenesis of the tooth. It also allows the possibility to keep teeth that otherwise will be extracted and cause an adverse effect to young growing individuals.

\section{Acknowledgement}

The author would like to thank Dr Kenneth J. Frick for the help received in editing this manuscript.

\section{References}

1. Sheehey EC, Roberts GJ (1997) Use of calcium hydroxide for apical barrier formation and healing in non-vital immature permanent teeth: A review. Br Dent J 183: 241-246. [Crossref]

2. Witherspoon DE (2008) Vital pulp therapy with new material: New directions and treatment perspectives-permanent teeth. J Endod 34: S25-28. [Crossref]

3. Bogen G, Kim JS, Bakland LK (2008) Direct pulp capping with mineral trioxide aggregate: an observational study. J Am Dent Assoc 139: 305-315. [Crossref]

Correspondence to: Rebeca Weisleder, DDS, Med, Department of Endodontics, University of Missouri Kansas City, 650 East 25th St, Kansas City, Missouri 64108-2784, USA, E-mail: weislederurowr@umkc.edu

Received: January 14 2017; Accepted: January 25, 2017; Published: January 28, 2017 
4. Fong CD, Davis MJ (2002) Partial pulpotomy for immature permanent teeth, its present and future. Pediatr Dent 24: 29-32. [Crossref]

5. McDougal RA, Delano EO, Caplan D, Sigurdsson A, Trope M (2004) Success of an alternative for interim management of irreversible pulpitis. J Am Dent Assoc 135: 1707 1712. [Crossref]

6. Torabinejad M, Goodacre CJ (2006) Endodontic or dental implant therapy: the factors affecting treatment planning. J Am Dent Assoc 137: 973-977. [Crossref]

7. Schwartz-Arad D, Levin L, Ashkenazi M (2004) Treatment options of untreatable traumatized anterior maxillary teeth for future use of dental implantation. Implant Dent 13: 120-128. [Crossref]
8. Mente J, Geletneky B, Ohle M, Koch MJ, Ding PG, et al. (2010) Mineral trioxide aggregate or calcium hydroxide direct pulp capping: an analysis of the clinical treatment outcome. $J$ Endod 36: 806-813. [Crossref]

9. Cvek M (1978) A clinical report on partial pulpotomy and capping with calcium hydroxide in permanent incisors with complicated crown fracture. J Endod 4: 232-237. [Crossref]

10. Witherspoon DE, Small JC, Harris GZ (2006) Mineral trioxide aggregate pulpotomies: a case series outcomes assessment. J Am Dent Assoc 137: 610-618. [Crossref]

11. Kakehashi S, Stanley HR, Fitzgerald RJ (1965) The effects of surgical exposures of dental pulps in germ-free and conventional laboratory rats. Oral Surg Oral Med Oral Pathol 20: 340-349. [Crossref]

Copyright: (C2017 Weisleder R. This is an open-access article distributed under the terms of the Creative Commons Attribution License, which permits unrestricted use, distribution, and reproduction in any medium, provided the original author and source are credited. 